\title{
Infekcyjne zapalenie wsierdzia w wytycznych Europejskiego Towarzystwa Kardiologicznego 2015 - co uległo zmianie od roku 2009?
}

\author{
2015 European Society of Cardiology guidelines for the management \\ of infective endocarditis - what has changed since 2009?
}

\author{
Tomasz Zapolski, Agnieszka Styczeń, Andrzej Wysokiński
}

Katedra i Klinika Kardiologii Uniwersytetu Medycznego w Lublinie

\section{Streszczenie}

Infekcyjne zapalenie wsierdzia (IE) stanowi dość rzadką jednostkę chorobową, należąc do niebezpiecznych, nierzadko śmiertelnych chorób układu sercowo-naczyniowego. Właściwe rozpoznanie IE jest uważane za jedno z najtrudniejszych w medycynie. Trudności diagnostyczne i terapeutyczne IE wynikają z niehomogenności choroby, nierzadkiego imitowania objawami klinicznymi innych schorzeń oraz podstępności przebiegu IE skutkującego poważnymi powikłaniami.

W związku z tym istnieje stała konieczność precyzyjnej weryfikacji przez panel ekspertów opublikowanych danych dotyczących postępowania w IE, a także konstruktywnej oceny procedur diagnostycznych i leczniczych dla tej jednostki chorobowej. Ostatnie wytyczne dotyczące zapobiegania, rozpoznawania i leczenia IE grupy roboczej Europejskiego Towarzystwa Kardiologicznego ukazały się w 2009 roku. Uaktualnienie tych zaleceń przyniósł rok 2015.

W niniejszej pracy zaprezentowano różnice pomiędzy wytycznymi z 2009 roku a wytycznymi z 2015 roku, ze szczególnym uwzględnieniem obecnego nacisku na multidyscyplinarne podejście do chorego z IE (tzw. endocarditis team) oraz przedstawieniem zmian w leczeniu tych pacjentów w kontekście szybkiego postępu w dziedzinie kardiologii, który dokonał się w ostatnim czasie.

Słowa kluczowe: infekcyjne zapalenie wsierdzia, wytyczne, grupa IE

Folia Cardiologica 2016; 11, 4: 293-302

\section{Wstęp}

Infekcyjne zapalenie wsierdzia (IE, infective endocarditis) jest chorobą śmiertelną [1, 2]. Częstość jej występowania różni się w zależności od kraju, pozostając w zakresie 3-10 przypadków/100 000 osób/ rok [3-6]. Zachorowalność znacząco wzrasta wraz z wiekiem, osiągając szczyt w przedziale wiekowym 70-80 lat, w którym notuje się 14,5 przypadku/100 000 osób/rok. We wszystkich badaniach epidemiologicznych stosunek pacjentów płci żeńskiej do pacjentów płci męskiej był większy lub równy 2:1. Dodat- kowo, kobiety mogą być obciążone gorszym rokowaniem i są poddawane operacjom zastawkowym rzadziej niż mężczyźni [7].

Pomimo poprawy diagnostyki i leczenia IE nadal pozostaje związane z wysoką śmiertelnością i poważnymi powikłaniami. Do niedawna wytyczne dotyczące IE opierały się głównie na opiniach ekspertów ze względu na niską częstość występowania choroby, brak randomizowanych badań i ograniczoną liczbę metaanaliz [8-12]. Wytyczne Europejskiego Towarzystwa Kardiologicznego (ESC, European Society of Cardiology) z 2009 roku dotyczące

Adres do korespondencji: dr hab. n. med. Tomasz Zapolski, Katedra i Klinika Kardiologii, Uniwersytet Medyczny w Lublinie, ul. Jaczewskiego 8 , 20-950 Lublin, tel. 8172442 55, faks 8172441 51, e-mail: zapolia@wp.pl 
zapobiegania, diagnostyki i leczenia IE wprowadziły kilka innowacyjnych koncepcji [13]. Uaktualnienie tych zaleceń przez ESC w 2015 roku uzasadnia kilka powodów: publikacja szeregu nowych badań, w tym pierwszego randomizowanego badania dotyczącego leczenia kardiochirurgicznego [14], ważnych postępów w badaniach obrazowych [15], szczególnie na polu medycyny nuklearnej oraz rozbieżności w stosunku do poprzednich wytycznych [10-13]. W ostatnim czasie podkreślono potrzebę zespołowego podejścia w postępowaniu z chorymi na IE (tzw. endocarditis team) $[16,17]$. Dodatkowo zwrócono uwage na rolę diagnostyki obrazowej w IE, zmodyfikowano kryteria jego rozpoznawania, omówiono szczegółowe wskazania do leczenia operacyjnego, wprowadzając definicję czasu operacji, oraz omówiono problematykę IE u pacjentów z elektrycznymi urządzeniami wszczepialnymi.

\section{Endocarditis team}

Infekcyjne zapalenie wsierdzia jest jednostką chorobową, która wymaga zespołowego podejścia z następujących powodów:

- IE nie jest jednolitą chorobą, ale raczej może się objawiać bardzo różnymi problemami w zależności od pierwotnie zajętego narządu, podstawowej choroby kardiologicznej, zaangażowanych mikroorganizmów, obecności lub braku powikłań oraz charakterystyki pacjenta [14];

- potrzebny jest bardzo wysoki poziom wiedzy lekarzy kilku specjalności, włączając w to kardiologów, kardiochirurgów, specjalistów chorób zakaźnych, neurologów, neurochirurgów, specjalistów od choroby niedokrwiennej serca i innych. Uważa się, że echokardiografia odgrywa główną rolę w diagnostyce i postępowaniu w przypadku IE, jakkolwiek inne techniki obrazowe, takie jak rezonans magnetyczny (MRI, magnetic resonance imaging), wielorzędowa tomografia komputerowa (MSCT, multislice computed tomography) oraz nuklearne badania obrazowe okazały się użyteczne w rozpoznawaniu, obserwacji i podejmowaniu decyzji u chorych z IE [15]. Włączenie do teamu wszystkich wymienionych specjalistów staje się coraz ważniejsze;

- około połowa pacjentów z IE jest poddawana zabiegowi chirurgicznemu w czasie hospitalizacji [17]. Wczesna konsultacja z zespołem chirurgów jest ważna i uważana za niezbędną we wszystkich przypadkach powikłanego infekcyjnego zapalenia wsierdzia, na przykład IE z niewydolnością serca (HF, heart failure), ropniem lub zatorem albo powikłaniami neurologicznymi.

W związku z tym istotna jest obecność endocarditis team. To multidyscyplinarne podejście okazało się użyteczne w postępowaniu w zastawkowych wadach serca [16] (Heart Valve Clinic), szczególnie w wyborze pacjentów do procedur przezcewnikowej implantacji zastawki aortal- nej [18]. W zakresie IE podejście zespołowe przyjęte we Francji, z włączeniem standaryzowanej terapii medycznej, wskazań chirurgicznych na podstawie wytycznych oraz jednorocznej dokładnej obserwacji, okazało się istotnie zmniejszać śmiertelność jednoroczną z 18,5\% do 8,2\% [19]. Inni autorzy donieśli ostatnio o podobnych efektach [20]. Reasumując wszystkie uzyskane wyniki, takie podejście zespołowe uzyskało ostatnio rekomendację w klasie IB w wytycznych American Heart Association/American College of Cardiology z roku 2014 dla postępowania z pacjentami z zastawkową chorobą serca [21].

\section{Definicja endocarditis team}

Na wzór Kardiogrupy (heart team) wprowadzono zespół lekarzy zajmujących się infekcyjnym zapaleniem wsierdzia, tak zwaną endocarditis team, to jest kardiologa, kardiochirurga, lekarza chorób zakaźnych, anestezjologa, mikrobiologa i innych, którzy wspólnie powinni podejmować decyzje o wyborze optymalnej metody leczenia pacjentów z IE. Udowodniono, że takie multidyscyplinarne podejście do chorego istotnie zmniejszało śmiertelność pacjentów z IE [22].

\section{Kiedy należy skonsultować pacjenta z IE z endocarditis team w centrum referencyjnym?}

Chorzy z powikłanym infekcyjnym zapaleniem wsierdzia (np. IE z HF, ropniem lub powikłaniami zatorowymi lub neurologicznymi związanymi z wadą wrodzoną serca) powinni być konsultowani we wczesnym okresie i prowadzeni w centrum referencyjnym z możliwością natychmiastowego leczenia kardiochirurgicznego.

Chorzy z niepowikłanym IE mogą być wstępnie leczeni w centrum niereferencyjnym, ale muszą pozostawać w regularnym kontakcie konsultacyjnym z centrum referencyjnym, konsultowani przez multidyscyplinarny endocarditis team, a kiedy zajdzie konieczność odbyć bezpośrednią konsultację w centrum referencyjnym (tab. 1) [22].

\section{Charakterystyka centrum referencyjnego}

Centrum referencyjne powinno mieć możliwość natychmiastowej dostępności do procedur diagnostycznych, z włączeniem echokardiografii przezklatkowej (TTE, transthoracic echocardiography), echokardiografii przezprzełykowej (TEE, transesophageal echocardiography), MSCT oraz badań izotopowych.

We wczesnych stadiach choroby, szczególnie w powikłanych przypadkach IE (HF, ropień, duże wegetacje, powikłania neurologiczne oraz zatorowe), konieczna jest natychmiastowa dostępność do leczenia kardiochirurgicznego.

Optymalnym i obecnie wymaganym rozwiązaniem jest obecność odpowiednich specjalistów w centrum referencyjnym (endocarditis team), z włączeniem przynajmniej kardiochirurgów, kardiologów i anestezjologów, specjali- 
Tabela 1. Zalecenia dotyczące konsultowania chorych w centrach referencyjnych (źródło [22])

\begin{tabular}{|c|c|c|}
\hline Zalecenia & $\begin{array}{l}\text { Klasa } \\
\text { zaleceń }\end{array}$ & $\begin{array}{l}\text { Poziom wiarygod- } \\
\text { ności danych }\end{array}$ \\
\hline $\begin{array}{l}\text { Chorzy z powikłanym IE powinni być oceniani i leczeni we wczesnym okresie choroby w centrum } \\
\text { referencyjnym, z możliwością natychmiastowego leczenia operacyjnego oraz dostępnym mul- } \\
\text { tidyscyplinarnym zespołem specjalistów endocarditis team, obejmującym specjalistów chorób } \\
\text { zakaźnych, mikrobiologów, kardiologów, specjalistów wykonujących badania obrazowe, kardio- } \\
\text { chirurgów, a jeśli to konieczne, także specjalistów od wad wrodzonych serca }\end{array}$ & Ila & B \\
\hline $\begin{array}{l}\text { Chorzy z niepowikłanym IE mogą być leczeni w niereferencyjnym ośrodku, z wczesną i regularną } \\
\text { komunikacją z centrum referencyjnym, a kiedy to konieczne, powinni być konsultowani osobiś- } \\
\text { cie w centrum referencyjnym }\end{array}$ & Ila & B \\
\hline
\end{tabular}

stów chorób zakaźnych, mikrobiologów, a kiedy to możliwe specjalistów wad zastawkowych serca, wad wrodzonych serca, specjalistów usuwających elektryczne urządzenia wszczepialne, echokardiografistów oraz specjalistów innych metod obrazowania, neurologów, neurochirurgów oraz radiologów zabiegowych [22].

\section{Zadania endocarditis team}

Endocarditis team powinna odbywać regularne spotkania w celu przedyskutowania przypadków, podejmowania decyzji dotyczących leczenia operacyjnego oraz określania sposobu dalszego postępowania i obserwacji chorego. Endocarditis team wybiera typ, czas trwania oraz rodzaj następczej antybiotykoterapii, zgodnie z wystandaryzowanym protokołem zgodnym z bieżącymi wytycznymi. Powinna też uczestniczyć w prowadzeniu narodowych oraz międzynarodowych rejestrów i publikować raporty śmiertelności i umieralności w swoim centrum referencyjnym. Ponadto powinna być włączona w program poprawy jakości, a także w program edukacyjny dla pacjentów. Dalszą obserwację chorych należy zorganizować na bazie wizyt ambulatoryjnych dostosowanych do klinicznego statusu indywidualnego pacjenta (najlepiej w 1., 3., 6. i po 12 miesiącach od wypisania ze szpitala, ponieważ większość niekorzystnych zdarzeń ma miejsce w tym przedziale czasowym) [22].

\section{Badania obrazowe w infekcyjnym zapaleniu wsierdzia}

W wytycznych ESC z 2015 roku rozszerzono wskazania do zastosowania echokardiografii w diagnostyce IE. Badanie to jest niezbędne zarówno w rozpoznawaniu IE, jak i monitorowaniu terapii medycznej. Istotne znaczenie ma również echokardiografia śródoperacyjna oraz po zakończeniu leczenia (tab. 2). Obecnie badanie to należy rozważyć u pacjenta z rozpoznaną bakteriemią o etiologii Staphylococcus aureus. Echokardiografia umożliwia wizualizację licznych specyficznych obrazów echokardiograficznych powikłań IE odpowiadających zmianom anatomopatologicznym (tab. 3). Spośród nich trzy: wegetacje, ropień okołozastawkowy oraz nowo stwierdzona dysfunkcja protezy zastawkowej stanowią duże kryteria rozpoznania IE [13, 23, 24].

Ponadto podkreślono dużą rolę bardziej zaawansowanych metod obrazowych: CT i pozytonowej tomografii emisyjnej z tomografią komputerową (PET-CT, positron emission tomography-computed tomography), co wpłynęło na modyfikację kryteriów rozpoznania IE - obie metody wraz z echokardiografią są rekomendowane w toku diagnostycznym IE [22]. Tomografia komputerowa jest szczególnie przydatna i rekomendowana w sytuacjach, kiedy konieczna jest ocena tętnic wieńcowych, a jednocześnie istnieje ryzyko embolizacji fragmentami wegetacji lub dekompensacji hemodynamicznej podczas inwazyjnej angiografii [25]. Rezonans magnetyczny, dzięki wyższej czułości w porównaniu z CT, zwiększa prawdopodobieństwo wykrycia mózgowych powikłań IE. Różne badania, w tym także uwzględniające przeglądową ocenę mózgu w MRI w czasie ostrej fazy IE jednoznacznie wskazują na występowanie zmian u 60-80\% chorych [26]. Od czasu włączenia uszkodzenia mózgu u pacjentów bez objawów neurologicznych do małych kryteriów Duke, przeglądowy MRI mózgu ma istotne znaczenie w diagnostyce IE [27]. Wprowadzenie metod hybrydowych zarówno do konwencjonalnej diagnostyki nuklearnej (np. komputerowej tomografii emisyjnej pojedynczego fotonu [SPECT-CT, single-photon emission computed tomography]), jak i do PET (np. PET-CT), sprawiło, że techniki medycyny nuklearnej stały się cennymi metodami uzupełniającymi w przypadkach trudności diagnostycznych u chorych z klinicznym podejrzeniem IE. Najważniejszą wartością dodaną wynikającą z zastosowania tych technik jest zmniejszenie liczby nierozpoznanych przypadków IE, klasyfikowanych dotychczas jako „możliwe IE" na podstawie klasycznych kryteriów Duke oraz wykrywanie obwodowych powikłań zatorowych i przerzutowych ognisk zakaźnych [28]. 
Tabela 2. Rola echokardiografii w infekcyjnym zapaleniu wsierdzia (źródło [22])

\begin{tabular}{|c|c|c|}
\hline Zalecenia & $\begin{array}{c}\text { Klasa } \\
\text { zaleceń }\end{array}$ & $\begin{array}{l}\text { Poziom wiarygod- } \\
\text { ności danych }\end{array}$ \\
\hline \multicolumn{3}{|l|}{ Rozpoznanie } \\
\hline TTE zalecane jest jako badanie obrazowe pierwszej linii w przypadkach podejrzenia IE & 1 & B \\
\hline $\begin{array}{l}\text { TEE zalecane jest u wszystkich chorych z klinicznym podejrzeniem IE oraz u chorych z negatyw- } \\
\text { nym lub niediagnostycznym wynikiem TTE }\end{array}$ & I & B \\
\hline $\begin{array}{l}\text { TEE zalecane jest u chorych z klinicznym podejrzeniem IE, kiedy mają wszczepione sztuczne } \\
\text { zastawki bądź urządzenia wewnątrzsercowe }\end{array}$ & I & B \\
\hline $\begin{array}{l}\text { Powtórzenie TTE i/lub TEE w ciągu 5-7 dnie zalecane jest w przypadkach, kiedy wstępne bada- } \\
\text { nie było negatywne, a istnieje duże podejrzenie kliniczne IE }\end{array}$ & I & $\mathrm{C}$ \\
\hline $\begin{array}{l}\text { Badanie echokardiograficzne powinno być brane pod uwagę w bakteriemii Staphylococcus au- } \\
\text { reus }\end{array}$ & Ila & B \\
\hline $\begin{array}{l}\text { TEE powinno być rozważane u chorych z podejrzeniem IE, nawet w przypadku pozytywnego wy- } \\
\text { niku TTE z wyjątkiem izolowanego IE na zastawkach natywnych prawej części serca przy dobrej } \\
\text { jakości badania oraz jednoznacznym wyniku TTE }\end{array}$ & Ila & $\mathrm{C}$ \\
\hline \multicolumn{3}{|l|}{ Monitorowanie terapii medycznej } \\
\hline $\begin{array}{l}\text { Powtórzenie TTE i/lub TEE zalecane jest jak najszybciej w przypadku podejrzenia nowego powi- } \\
\text { kłania IE (nowy szmer, zator, przedłużająca się gorączka, niewydolność krążenia, ropień, blok } \\
\text { przedsionkowo-komorowy) }\end{array}$ & I & B \\
\hline $\begin{array}{l}\text { Powtórzenie TTE i/lub TEE powinno być rozważane podczas follow-up niepowikłanego IE w celu } \\
\text { rozpoznania nowego bezobjawowego powikłania lub monitorowania wielkości wegetacji. Czas } \\
\text { oraz rodzaj powtarzanego badania (TTE lub TEE) zależy od wyjściowych znalezisk, typu drobno- } \\
\text { ustrojów oraz wstępnej odpowiedzi na leczenie }\end{array}$ & Ila & B \\
\hline \multicolumn{3}{|l|}{ Echokardiografia śródoperacyjna } \\
\hline $\begin{array}{l}\text { Śródoperacyjne badanie echokardiograficzne zalecane jest we wszystkich przypadkach IE wy- } \\
\text { magających leczenia operacyjnego }\end{array}$ & I & B \\
\hline \multicolumn{3}{|l|}{ Echokardiografia po zakończeniu leczenia } \\
\hline $\begin{array}{l}\text { TTE zalecane jest po zakończeniu terapii antybiotykowej w celu oceny morfologii i czynności } \\
\text { serca i zastawek }\end{array}$ & I & $\mathrm{C}$ \\
\hline
\end{tabular}

IE (infective endocarditis) - infekcyjne zapalenie wsierdzia; TEE (transesophageal echocardiography) - echokardiografia przezprzelykowa; TTE (transthoracic echocardiography) - echokardiografia przezklatkowa

Tabela 3. Definicje anatomiczne i echokardiograficzne (źródło [22])

\begin{tabular}{|c|c|c|}
\hline Powikłanie & Chirurgia/sekcja & Echokardiografia \\
\hline Wegetacja & $\begin{array}{l}\text { Zainfekowana masa połączona ze wsierdziem serca } \\
\text { lub implantowanym materiałem wewnątrzsercowym }\end{array}$ & $\begin{array}{l}\text { Poruszająca się lub nieruchoma masa związana z za- } \\
\text { stawką, inną strukturą wewnątrzsercową lub sztucznym } \\
\text { materiałem }\end{array}$ \\
\hline Ropień & $\begin{array}{l}\text { Przestrzeń okołozastawkowa wypełniona materiałem } \\
\text { nekrotycznym lub ropą niekomunikująca się ze świat- } \\
\text { łem układu sercowo-naczyniowego }\end{array}$ & $\begin{array}{l}\text { Pogrubiały, niehomogenny hipo- lub hiperechogeniczny } \\
\text { obszar w obrębie pierścienia zastawki }\end{array}$ \\
\hline Pseudotętniak & $\begin{array}{l}\text { Przestrzeń okołozastawkowa komunikująca się ze } \\
\text { światłem układu sercowo-naczyniowego }\end{array}$ & $\begin{array}{l}\text { Okołozastawkowa przestrzeń bezechowa z obecnym } \\
\text { przepływem w badaniu dopplerowskim }\end{array}$ \\
\hline Perforacja & Przerwanie ciągłości tkanek wsierdzia & $\begin{array}{l}\text { Przerwanie ciągłości tkanki wewnątrzsercowej z obec- } \\
\text { nym przepływem dopplerowskim w obrębie szczeliny }\end{array}$ \\
\hline Przetoka & Komunikacja pomiędzy dwiema sąsiadującym jamami & Połączenie dwóch jam przez perforację \\
\hline Tętniak zastawki & Woreczkowate uwypuklenie tkanek okołozastawkowych & Woreczkowate uwypuklenie zastawki \\
\hline $\begin{array}{l}\text { Wyprucie protezy } \\
\text { zastawkowej }\end{array}$ & Wyprucie protezy & $\begin{array}{l}\text { Przeciek okołozastawkowy rozpoznany przy pomocy TTE } \\
\text { i/lub TEE z rotacyjnym ruchem zastawki lub bez niego }\end{array}$ \\
\hline
\end{tabular}


Tabela 4. Definicje terminów użytych w zmodyfikowanych w 2015 roku kryteriach Europejskiego Towarzystwa Kardiologicznego rozpoznawania infekcyjnego zapalenia wsierdzia (IE, infective endocarditis) (zmodyfikowano wg [27])

\section{Kryteria duże}

\section{Dodatnie dla IE posiewy krwi}

a) Typowe drobnoustroje charakterystyczne dla IE w 2 oddzielnych posiewach krwi:

- Viridans streptococci, Streptococcus gallolyticus (Streptococcus bovis), grupa HACEK, Staphylococcus aureus lub

- pozaszpitalne enterokoki, w przypadku braku pierwotnego ogniska lub

b) Drobnoustroje charakterystyczne dla IE wyhodowane z przewlekle dodatnich posiewów krwi:

- $\geq 2$ dodatnie posiewy krwi z próbek pobranych w odstępach $>12$ h lub

- wszystkie 3 lub większość z $\geq 4$ odrębnych posiewów krwi (z przynajmniej 1-godz. odstępami) lub

c) Pojedynczy dodatni posiew krwi dla Coxiella burnetii lub faza I przeciwciała IgG w mianie > 1:800

\section{Pozytywne badania obrazowe w IE}

a) Pozytywny wynik badania echokardiograficznego w IE:

- wegetacja

- ropień, pseudotętniak, przetoka wewnątrzsercowa

- perforacja zastawki lub tętniaka

- nowe częściowe wyprucie sztucznej zastawki

b) Nieprawidłowa aktywność wokół implantowanej sztucznej zastawki wykryta przy pomocy ${ }^{18} \mathrm{~F}$-FDG PET-CT (tylko jeśli zastawka była implantowana > 3 miesięcy) lub w SPECT-CT znakowanymi izotopowo leukocytami

c) Niewątpliwy przeciek okołozastawkowy wykazany w CT

\section{Kryteria małe}

Predyspozycja rozumiana jako predysponujące warunki w sercu lub stosowanie substancji dożylnych

Gorączka zdefiniowana jako temperatura $>38^{\circ} \mathrm{C}$

Zmiany naczyniopochodne (włączając $w$ to tylko stwierdzone przy pomocy badań obrazowych): duże zatory tętnicze, septyczne zawały płuc, zakażone (mykotyczne) tętniaki, krwawienie wewnątrzczaszkowe, krwawienia ze śluzówek oraz objaw Janeway’a

Zmiany immunologiczne: kłębuszkowe zapalenie nerek, guzki Oslera, plamki Rotha oraz obecność czynnika reumatoidalnego

Dowody mikrobiologiczne: dodatnie posiewy krwi, ale niespełniające warunków dla uznania ich za duże kryterium, jak napisano wyżej, lub dowody serologiczne aktywnej infekcji drobnoustrojami związanymi z IE

CT (computed tomography) - tomografia komputerowa; PET-CT (positron emission tomography-computed tomography) - pozytonowa tomografia emisyjna z tomografią komputerowa; SPECT-CT (single-photon emission computed tomography) - komputerowa tomografia emisyjna pojedynczego fotonu

\section{Kryteria rozpoznawania infekcyjnego zapalenia wsierdzia}

W obecnych „Wytycznych ESC dotyczących leczenia IE w 2015 roku" kryteria rozpoznawania IE uległy modyfikacji w stosunku do wytycznych z roku 2009. Mając na uwadze ostatnio opublikowane wyniki badań, wprowadzono do kryteriów diagnostycznych trzy nowe punkty. Po pierwsze uznano, iż stwierdzenie nieprawidłowości okołozastawkowych należy traktować jako kryterium duże. Jako kryterium duże, w sytuacji podejrzenia IE dotyczącego sztucznej zastawki, zalecono także traktować nieprawidłową aktywność wokół miejsca wszczepienia zastawki, stwierdzoną w PET-CT z użyciem ${ }^{18}$ F-FDG PET-CT (wyłącznie jeśli od czasu wszczepienia zastawki upłynęły $>3$ miesiące) lub w SPECT-CT z zastosowaniem znakowanych izotopowo leukocytów. Stwierdzenie w badaniach obrazowych świe- żych ognisk zatorowych lub zakażonych tętniaków (zmiany klinicznie bezobjawowe) włączono natomiast do kryteriów małych (tab. 4).

W związku z tym stworzono nowy algorytm diagnostyki IE zawarty w standardach ESC z 2015 roku [22]. Rozpoznanie IE nadal opiera się na kryteriach Duke ze szczególną rolą echokardiografii oraz diagnostyki mikrobiologicznej. Podkreślono, iż w przypadkach wstępnego podejrzenia lub nawet wykluczenia IE, lecz jednocześnie przy utrzymującym się wysokim klinicznym podejrzeniem choroby ważne jest powtarzanie badań echokardiograficznych i wykonywanych seryjnie posiewów krwi. Konieczne jest także zastosowanie innych metod obrazowych zarówno w celu potwierdzenia zajęcia serca (CT serca, ${ }^{18}$ F-FDG PET-CT lub SPECT-CT znakowanymi izotopowo leukocytami), jak i w celu wykrycia ognisk zatorowych (MRI mózgu, CT całego ciała i/lub PET-CT) (ryc. 1). 


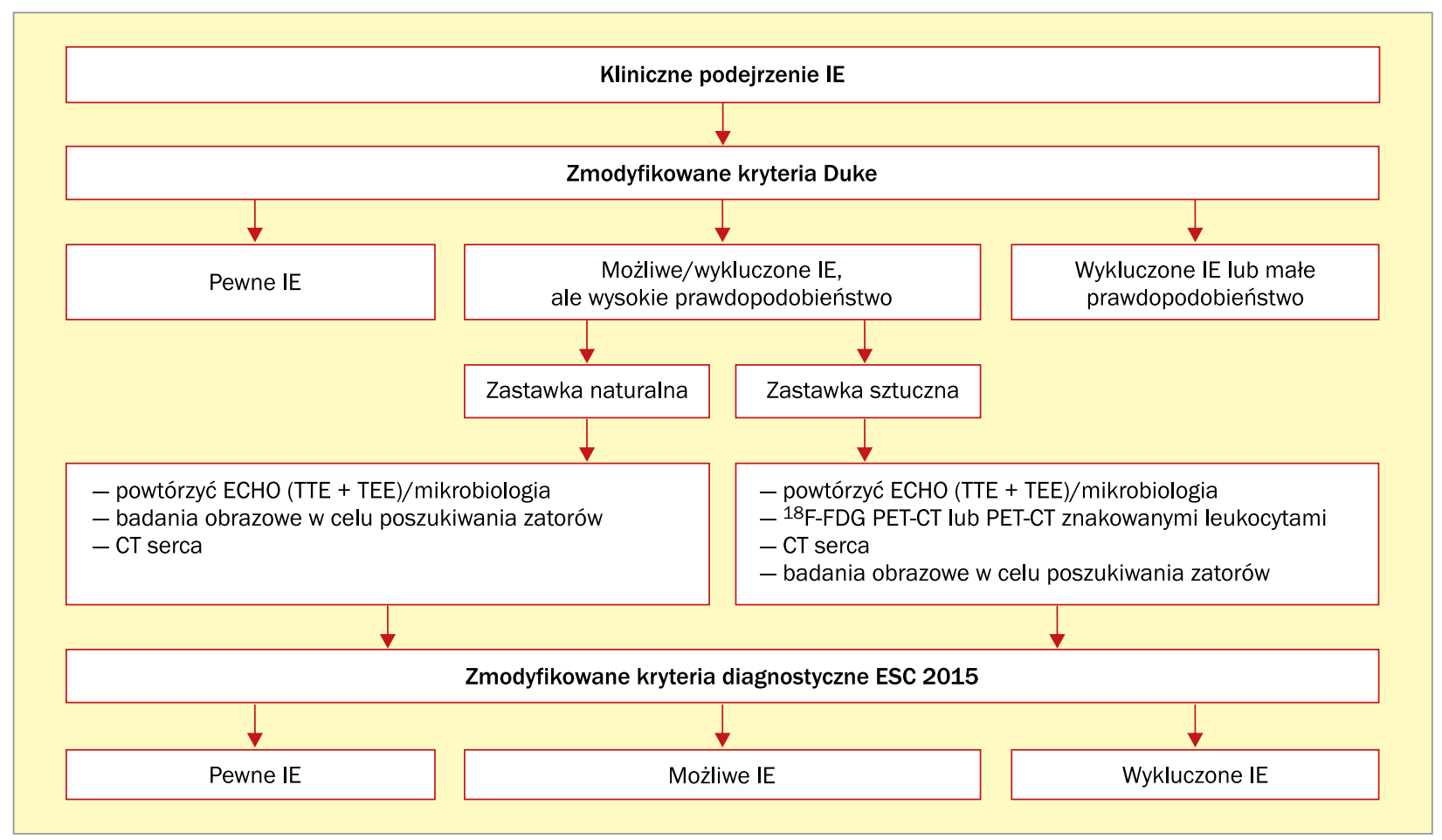

Rycina 1. Algorytm diagnostyki infekcyjnego zapalenia wsierdzia (IE, infective endocarditis) według standardów Europejskiego Towarzystwa Kardiologicznego (ESC, European Society of Cardiology) 2015; CT (computed tomography) - tomografia komputerowa; FDG - fluorodezoksyglukoza; PET (positron emission tomography) - pozytonowa tomografia emisyjna; SPECT (single-photon emission computed tomography) - emisyjna tomografia komputerowa pojedynczego fotonu; TTE (transthoracic echocardiography) - echokardiografia przezklatkowa; TEE (transesophageal echocardiography) - echokardiografia przezprzełykowa) [22]

\section{Leczenie operacyjne infekcyjnego zapalenia wsierdzia}

Zmodyfikowano wskazania do leczenia operacyjnego IE. W nowych wytycznych ESC 2015 szczegółowo sprecyzowano optymalny czas do interwencji kardiochirurgicznej w IE. Dodatkowo zwrócono uwagę na zasadność zapobiegania epizodom zatorowym i wskazano sytuacje, w których należy przeprowadzić ratunkowy lub pilny zabieg operacyjny (tab. 5) [22].

Nowością w wytycznych ESC 2015 dla IE są definicje czasu operacji. Zgodnie z nimi, zabiegiem ratunkowym nazywany jest zabieg wykonany w czasie do 24 godzin od rozpoczęcia antybiotykoterapii. Za zabieg pilny uważa się zabieg przeprowadzony w ciągu kilku dni, poniżej 7 dni od rozpoczęcia leczenia antybiotykiem. Operacją elektywną jest operacja w czasie pierwszego lub drugiego tygodnia antybiotykoterapii [22].

\section{Elektryczne urządzenia implantowalne}

W wytycznych ESC 2015 wyraźnie podkreślono konieczność całkowitego usunięcia układu, optymalnie drogą przezskórną, a także ocenę wskazań do ponownej implantacji urządzenia. Wprowadzono również odrębne zalecenia dotyczące profilaktyki IE związanej z implantacją urządzeń elektrycznych (tab. 6) [22]. 
Tabela 5. Wskazania oraz czas leczenia operacyjnego w infekcyjnym zapaleniu wsierdzia (IE, infective endocarditis) lewego serca (IE na zastawkach natywnych oraz sztucznych) (źródło [22])

\begin{tabular}{|c|c|c|c|}
\hline Zalecenia & Czas & $\begin{array}{c}\text { Klasa } \\
\text { zaleceń }\end{array}$ & $\begin{array}{l}\text { Poziom } \\
\text { wiarygodności } \\
\text { danych }\end{array}$ \\
\hline \multicolumn{4}{|l|}{ Niewydolność krążenia } \\
\hline $\begin{array}{l}\text { IE związane z natywną lub sztuczną zastawką aortalną lub mitralną z ciężką jej niedo- } \\
\text { mykalnością, obstrukcją lub przetoką powodującą oporne na leczenie obrzęk płuc lub } \\
\text { wstrząs kardiogenny }\end{array}$ & $\begin{array}{l}\text { Ratunko- } \\
\text { wa }\end{array}$ & 1 & B \\
\hline $\begin{array}{l}\text { IE związane z natywną lub sztuczną zastawką aortalną lub mitralną z ciężką jej niedo- } \\
\text { mykalnością, obstrukcją powodującą objawy niewydolności krążenia lub echokardio- } \\
\text { graficzne cechy złej wydolności hemodynamicznej }\end{array}$ & Pilna & I & B \\
\hline \multicolumn{4}{|l|}{ Niekontrolowana infekcja } \\
\hline $\begin{array}{l}\text { Miejscowa, niekontrolowana infekcja (ropień, pseudotętniak, przetokowa, powiększają- } \\
\text { ca się wegetacja) }\end{array}$ & Pilna & I & B \\
\hline Infekcja spowodowana przez grzyby lub mikroorganizmy oportunistyczne & $\begin{array}{l}\text { Pilna/elek- } \\
\text { tywna }\end{array}$ & I & C \\
\hline $\begin{array}{l}\text { Utrzymujące się dodatnie posiewy krwi mimo właściwej antybiotykoterapii oraz ade- } \\
\text { kwatnej kontroli septycznych ognisk przerzutowych }\end{array}$ & Pilna & Ila & B \\
\hline $\begin{array}{l}\text { IE związane ze sztuczną zastawką spowodowane przez gronkowce lub inne niż HACEK } \\
\text { gram-ujemne bakterie }\end{array}$ & $\begin{array}{l}\text { Pilna/elek- } \\
\text { tywna }\end{array}$ & Ila & C \\
\hline \multicolumn{4}{|l|}{ Zapobieganie zatorom } \\
\hline $\begin{array}{l}\text { IE związane z natywną lub sztuczną zastawką aortalną lub mitralną z utrzymującymi } \\
\text { się wegetacjami o wielkości > } 10 \text { mm po jednym lub więcej epizodach zatorowych } \\
\text { mimo właściwej terapii antybiotykowej }\end{array}$ & Pilna & I & B \\
\hline $\begin{array}{l}\text { IE związane z natywną lub sztuczną zastawką aortalną lub mitralną z wegetacjami } \\
\text { o wielkości > } 10 \text { mm, związane z ciężką stenozą lub niedomykalnością aortalną przy } \\
\text { niskim ryzyku operacyjnym }\end{array}$ & Pilna & Ila & B \\
\hline $\begin{array}{l}\text { IE związane z natywną lub sztuczną zastawką aortalną lub mitralną z izolowanymi bar- } \\
\text { dzo dużymi wegetacjami (> } 30 \mathrm{~mm} \text { ) }\end{array}$ & Pilna & Ila & B \\
\hline $\begin{array}{l}\text { IE związane z natywną lub sztuczną zastawką aortalną lub mitralną z izolowanymi bar- } \\
\text { dzo dużymi wegetacjami (> } 15 \mathrm{~mm} \text { ) bez innych wskazań do leczenia operacyjnego }\end{array}$ & Pilna & IIb & $C$ \\
\hline
\end{tabular}


Tabela 6. Infekcyjne zapalenie wsierdzia (IE, infective endocarditis) związane z implantowanymi urządzeniami (źródło [22])

$\begin{array}{cc}\text { Zalecenia } & \text { Klasa zaleceń } \begin{array}{c}\text { Poziom } \\ \text { wiarygodności } \\ \text { danych }\end{array} \\ & \end{array}$

\section{Rozpoznanie}

Zaleca się pobranie co najmniej 3 posiewów krwi przed włączeniem antybiotykoterapii z powodu zakażenia CIED

Wskazany jest posiew z końcówki elektrody, jeśli eksplantowano CIED

TEE jest zalecane u pacjentów z podejrzeniem CDRIE z dodatnimi lub ujemnymi wynikami posiewów krwi niezależnie od wyniku TTE w celu oceny IE związanego z elektrodą lub zastawką serca

Można rozważyć wykonanie echokardiografii wewnątrzsercowej u pacjentów z podejrzeniem CDRIE, dodatnimi wynikami posiewu krwi i ujemnymi wynikami TTE i TEE

Można rozważyć wykonanie scyntygrafii znakowanymi leukocytami i ${ }^{18}$ FDG PET-CT u osób z podejrzeniem CDRIE, dodatnimi posiewami krwi i ujemnym wynikiem echokardiografii

\section{Zasady leczenia}

Przedłużona (np. przed i po usunięciu) antybiotykoterapia i pełne usunięcie układu (urządzenia i elektrody) są zalecane w CDRIE, podobnie jak w przypadku izolowanej infekcji loży

Całkowite usunięcie układu należy rozważyć w przypadku jawnej infekcji bez widocznego źródła infekcji

U pacjentów z IE na zastawce natywnej lub sztucznej i z urządzeniem wewnątrzsercowym w przypadku braku objawów zakażenia układu można rozważyć pełne usunięcie układu

\section{Sposób usunięcia urządzenia}

Przezskórne usunięcie układu jest zalecane u większości pacjentów z CDRIE, nawet w przypadku wegetacji > $10 \mathrm{~mm}$

Chirurgiczne usunięcie układu należy rozważyć, gdy przezskórne usunięcie jest niekompletne lub niemożliwe do wykonania bądź gdy jest ciężka niedomykalność trójdzielna

Chirurgiczne usunięcie układu można rozważyć u pacjentów z dużymi wegetacjami (> 20 mm)

\section{Reimplantacja}

Po usunięciu układu zaleca się ponowną oceną wskazań do reimplantacji układu

Reimplantacja powinna być odłożona w czasie tak długo, jak to możliwe (kilka dni, tygodni antybiotykoterapii), wtedy gdy jest to wskazane

Czasową implantację układu po przeciwnej stronie można rozważyć u pacjentów stymulatorozależnych, wymagających odpowiedniej antybiotykoterapii przed reimplantacją

Czasowa stymulacja nie jest rutynowo zalecana

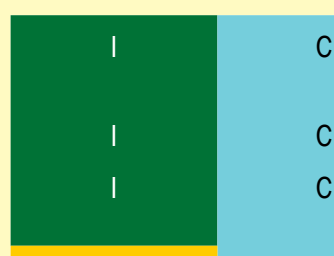

$\mathrm{Ilb}$

IIb
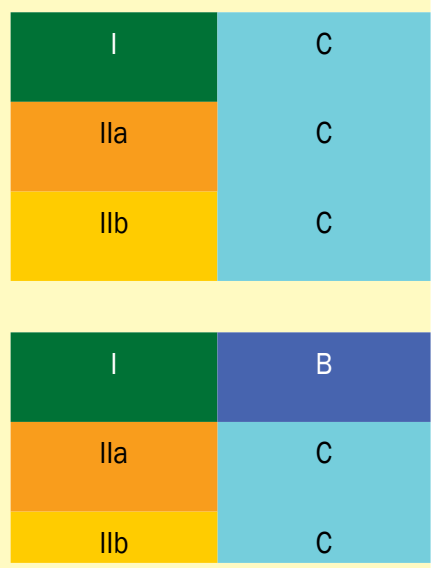

\begin{tabular}{cl} 
I & C \\
Ila & C \\
\hline IIb & C \\
III & C \\
\hline
\end{tabular}

\section{Profilaktyka}

Rutynowa antybiotykoterapia jest zalecana przed implantacją układu

Należy usunąć potencjalne źródła posocznicy w ciągu $\geq 2$ tygodni przed implantacją wewnątrznaczyniowego/sercowego ciała obcego, z wyjątkiem pilnych zabiegów

$\begin{array}{cc}\text { I } & \text { B } \\ \text { lla } & \text { C }\end{array}$

CIED (cardiovascular implantable electronic devices) - kardiologiczne urządzenia wszczepialne; CDRIE (cardiac device-related infective endocarditis) - infekcyjne zapalenie wsierdzia związane z urządzeniem medycznym; ET-CT (positron emission tomography-computed tomography) - pozytonowa tomografia emisyjna z tomografią komputerową; TTE (transthoracic echocardiography) - echokardiografia przezklatkowa; TEE (transesophageal echocardiography) - echokardiografia przezprzełykowa) 


\section{Abstract}

Infective endocarditis (IE) constitutes a rather rare disease, belonging to dangerous and not infrequently lethal illnesses of cardiovascular system. Adequate IE diagnosis is regarded as one of the most challenging in medicine. Diagnostic and therapeutic difficulties in infective endocarditis arise from non-homogeneity of the disease, its clinical symptoms frequently mimicking other diseases and IE insidious course resulting in serious complications.

Therefore, there is a constant necessity for precise verification of data concerning IE treatment as well as constructive assessment of diagnostic and therapeutic procedures by a panel of experts. The latest guidelines of the European Society of Cardiology Task Force on prevention, diagnosis and treatment of infective endocarditis were published in 2009. The year 2015 has brought their update.

This review presents differences between the guidelines from the year 2009 and the year 2015, with special consideration of current emphasis on multidisciplinary approach in patients diagnosed with IE (Endocarditis Team) and outlining changes in those patients' treatment in the context of fast progress in the field of cardiology that has been made lately.

Key words: endocarditis, guidelines, endocarditis team

Folia Cardiologica 2016; 11, 4: 293-302

\section{Piśmiennictwo}

1. Thuny F., Grisoli D., Collart F. i wsp. Management of infective endocarditis: challenges and prospectives. Lancet 2012; 379: 965-975.

2. Habib G. Management of infective endocarditis. Heart 2006; 92: 124-130.

3. Hoen B., Alla F., Selton-Suty C. i wsp. Changing profile of infective endocarditis: results of a 1-year survey in France. JAMA 2002; 288: 75-81.

4. Hogevik H., Olaison L., Andersson R. i wsp. Epidemiologic aspects of infective endocarditis in an urban population. A 5-year prospective study. Medicine (Baltimore) 1995; 74: 324-339.

5. Berlin J.A., Abrutyn E., Strom B.L. i wsp. Incidence of infective endocarditis in the Delaware Valley, 1988-1990. Am. J. Cardiol. 1995; 76: 933-936.

6. van der Meer J.T., Thompson J., Valkenburg H.A. i wsp. Epidemiology of infective endocarditis in The Netherlands. I. Patient characteristics. Arch. Intern. Med. 1992; 152: 1863-1868.

7. Aksoy 0., Meyer L.T., Cabell C.H. i wsp. Gender differences in infective endocarditis: pre- and co-morbid conditions lead to different management and outcomes in female patients. Scand. J. Infect. Dis. 2007; 39: 101-107.

8. Horstkotte D., Follath F., Gutschik E. i wsp. Guidelines on prevention, diagnosis and treatment of infective endocarditis executive summary: the Task, Force of Infective Endocarditis of the European Society of Cardiology. Eur. Heart J. 2004; 25: 267-276.

9. Naber C.K., Erbel R., Baddour L.M. i wsp. New guidelines for infective endocarditis: a call for a collaborative research. Int. J. Antimicrob. Agents 2007; 29: 615-616.

10. Wilson W., Taubert K.A., Gewitz M. i wsp. Prevention of infective endocarditis: a guideline from the American Heart Association Rheumatic Fever, Endocarditis, and Kawasaki Disease Committee, Council on Cardiovascular Surgery and Anesthesia, and the Quality of Care and Outcomes Research Interdisciplinary Working Group. Circulation 2007; 116: 1736-1754.
11. Baddour L.M., Wilson W.R., Bayer A.S. i wsp. Infective endocarditis: diagnosis, antimicrobial therapy, and management of complications: a statement for Healthcare Professional from the Committee of Rheumatic Fever, Endocarditis, and Kawasaki Disease, Council on Cardiovascular Disease in the Young, and the Councils on Clinical Cardiology, Stroke, and Cardiovascular Surgery and Anesthesia, American Heart Association: endorsed by the Infectious Diseases Society of America. Circulation 2005; 111: e394-e434.

12. Nishimura R.A., Carabello B.A., Faxon D.P. i wsp. ACC/AHA 2008 guideline update on valvular heart disease: focused update on infective endocarditis: a report of the American College of Cardiology/American Heart Association Task Force on Practice Guidelines: endorsed by the Society of Cardiovascular Anesthesiologists, Society for Cardiovascular Angiography and Interventions, and Society of Thoracic Surgeons. Circulation 2008; 118: 887-896.

13. Habib G., Hoen B., Tornos P. i wsp. Guidelines on the prevention, diagnosis, and treatment of infective endocarditis (new version 2009): the Task Force on the Prevention, Diagnosis and Treatment of Infective Endocarditis of the European Society of Cardiology (ESC). Endorsed by the European Society of Clinical Microbiology and Infectious Diseases (ESCMID) and the International Society of Chemotherapy (ISC) for Infection and Cancer. Eur. Heart J. 2009; 30: 2369-2413.

14. Kang D.H., Kim Y.J., Kim S.H. i wsp. Early surgery versus conventional treatment for infective endocarditis. N. Engl. J. Med. 2012; 366: 2466-2473.

15. Bruun N.E., Habib G., Thuny F. i wsp. Cardiac imaging in infectious endocarditis. Eur. Heart J. 2014; 35: 624-632.

16. Lancelotti P., Rosenhek R., Pibarot P. i wsp. ESC Working Group on Valvular Heart Disease position paper - heart valve clinics: organization, structure, and experiences. Eur. Heart J. 2013; 34: 1597-1606. 
17. Tornos P., lung B., Permanyer-Miralda G. i wsp. Infective endocarditis in Europe: lessons from the Euro heart survey. Heart 2005; 91 : 571-575.

18. Vahanian A., Alfieri O., Andreotti F. i wsp. Guidelines on the management of valvular heart disease (version 2012). Eur. Heart J. 2012; 33: 2451-2496.

19. Botelho-Nevers E., Thuny F., Casalta J.P. i wsp. Dramatic reduction in infective endocarditis-related mortality with a management-based approach. Arch. Intern. Med. 2009; 169: 1290-1298.

20. Chirillo F., Scotton P., Rocco F. i wsp. Impact of a multidisciplinary management strategy on the outcome of patients with native valve infective endocarditis. Am. J. Cardiol. 2013; 112: 1171-1176.

21. Nishimura R.A., Otto C.M., Bonow R.O. i wsp. 2014 AHA/ACC guideline for the management of patients with valvular heart disease: executive summary: a report of the American College of Cardiology/American Heart Association Task Force on Practice Guidelines. J. Am. Coll. Cardiol. 2014; 63: 2438-2488.

22. Habib G., Lancelotti P., Antunes M.J. i wsp. 2015 ESC Guidelines for the management of infective endocarditis. The Task Force for the Management of Infective Endocarditis of the European Society of Cardiology (ESC). Eur. Heart J. 2015; 36: 3075-3128.
23. Habib G., Badano L., Tribouilloy C. i wsp. Recommendations for the practice of echocardiography in infective endocarditis. Eur. J. Echocardiogr. 2010; 11: 202-219.

24. Mugge A., Daniel W.G., Frank G., Lichtlen P.R. Echocardiography in infective endocarditis: reassessment of prognostic implications of vegetation size determined by the transthoracic and the transesophageal approach. J. Am. Coll. Cardiol. 1989; 14: 631-638.

25. Hekimian G., Kim M., Passefort S. i wsp. Preoperative use and safety of coronary angiography for acute aortic valve infective endocarditis. Heart 2010; 96: 696-700.

26. Snygg-Martin U., Gustafsson L., Rosengren L. i wsp. Cerebrovascular complications in patients with left-sided infective endocarditis are common: a prospective study using magnetic resonance imaging and neurochemical brain damage markers. Clin. Infect. Dis. 2008; 47: 23-30.

27. Li J.S., Sexton D.J., Mick N. i wsp. Proposed modifications to the Duke criteria for the diagnosis of infective endocarditis. Clin. Infect. Dis. 2000; 30: 633-638.

28. Saby L., Laas 0., Habib G. i wsp. Positron emission tomography/ /computed tomography for diagnosis of prosthetic valve endocarditis: increased valvular ${ }^{18} \mathrm{~F}$-fluorodeoxyglucose uptake as a novel major criterion. J. Am. Coll. Cardiol. 2013; 61: 2374-2382. 